\title{
Herbicidal Activity and Residual States of Metolachlor in Upland Soil*
}

\author{
Hirosi Sugiyama** and Katsuichiro Kobayashi**
}

\begin{abstract}
The residues of metolachlor [2chloro-2'-ethyl- $N$-(2-methoxy-1-methylethyl)6 -methylacetanilide] applied to a soybean field were determined separately as to water-soluble and water-insoluble ingredients and were found to fluctuate with precipitation. The half life of all metolachlor was calculated as 40 to 60 days in 1990 and 4 to 5 days in 1991. The half life of the water-soluble ingredients, however, was as 6 to 12 days in 1990 and 3 days in 1991. Plant growth of Italian ryegrass in soils collected periodically after metolachlor application was inhibited, and this inhibition was closely related to the concentration of the water-soluble ingredients but little to that of the water-insoluble ingredients. This confirmed that the inhibition of plant growth by soil-applied metolachlor was induced by its water-soluble ingredients, while concentration of the herbicide in the soil water fluctuated little with the amount of precipitation, as different amounts of precipitation caused little variation in activity.
\end{abstract}

Key words : metolachlor, water soluble ingredients, soil water, residue in soil, herbicidal activity

\section{Introduction}

Metolachlor [2-chloro-2'-ethyl-N-(2methoxy-1-methylethyl)-6'-methylacetanilide], is widely applied to soil in annual upland weed

\footnotetext{
* A part of this work was reported at the 31st Annual Meeting of the Weed Science Society of Japan in 1991.

** National Agriculture Research Center, Tsukuba, Ibaraki 305, Japan

(Received May 19, 1993)
}

control. Many reports have given the adsorption, mobility, residue and performance of metolachlor in soils ${ }^{2,3,8,9,14)}$, its inhibitory characteristics on plant growth ${ }^{4)}$, the effects of residue on rice $^{1)}$ and influence of soil water content on metolachlor injury to corn $^{10,13)}$. However, these reports have provided little information on the relationship between the performance of metolachlor in soil and its inhibitory activity on plant growth. In our previous reports ${ }^{11,12)}$, the inhibitory activities of butachlor [ $N$-(butoxymethyl)-2-chloro- $2^{\prime}, 6^{\prime}-$ diethylacetanilide], pretilachlor [2-chloro- $2^{\prime}, 6^{\prime}-$ diethyl- $N$-(2-propoxyethyl)acetanilide ] and mefenacet [2-(benzothiazol-2-yloxy)- $N$-methylacetanilide], were shown to be clearly related to the concentrations of water-soluble ingredients in paddy soil. It was also suggested that the inhibitory activity of soil-applied herbicides was dependent on the concentration of water-soluble ingredients in the soil.

The objectives of this study were to confirm the relationship between the inhibitory activity of metolachlor applied to upland soil on plant growth and ingredient concentration in soil water with different amounts of precipitation.

\section{Materials and Methods}

\section{Soybean cultivation and metolachlor applica- tion}

Soybean (Glycine max Merr. cv. 'Enrei') was cultivated following conventional cropping in an upland field of National Agriculture Research Center in Tsukuba City (light-colored andosol, total carbon : $3.29 \%$, total nitrogen : $0.29 \%$, phosphate adsorption coefficient:2,241, cation 
Table 1. Precipitation and temperature during the 60 days after application of metolachlor to the soybean field.

\begin{tabular}{|c|c|c|c|c|}
\hline $\begin{array}{l}\text { Application } \\
\text { date }\end{array}$ & $\begin{array}{l}\text { Soil sampling } \\
\text { following } \\
\text { application } \\
\text { (days) }\end{array}$ & \multicolumn{2}{|c|}{$\underset{(\mathrm{mm})}{\text { Precipitation }}$} & $\begin{array}{c}\text { Average } \\
\text { temperature } \\
\left({ }^{\circ} \mathrm{C}\right)\end{array}$ \\
\hline \multirow[t]{7}{*}{1990.6 .22} & 0 & \multirow[b]{7}{*}{ total } & & \\
\hline & & & 3.5 & 21.7 \\
\hline & 10 & & & \\
\hline & & & 49.5 & 23.2 \\
\hline & \multirow{3}{*}{60} & & 83.0 & 26.4 \\
\hline & & & & \\
\hline & & & 136.0 & 24.5 \\
\hline \multirow[t]{8}{*}{1991.6 .26} & 0 & \multirow{2}{*}{\multicolumn{2}{|c|}{101.5}} & \multirow[b]{2}{*}{23.8} \\
\hline & & & & \\
\hline & \multirow[t]{2}{*}{12} & & & \\
\hline & & & 32.5 & 24.5 \\
\hline & \multirow[t]{2}{*}{30} & & & \\
\hline & & & 154.0 & 24.6 \\
\hline & \multirow[t]{2}{*}{60} & & & \\
\hline & & total & 288.0 & 24.4 \\
\hline
\end{tabular}

exchange capacity : $19.0 \mathrm{me} / 100 \mathrm{~g}$, clay content : $12.0 \%$ ). An emulsifiable concentrate of metolachlor (ai 45\%, 'Dual') was diluted with water and applied to the soil surface with a hand sprayer immediately after the seeding of soybean. The row areas where soybean was sown were treated with more of the herbicide than the furrows. Two rates of dosage, $1.8 \mathrm{~kg}$ and $3.6 \mathrm{~kg}$ ai $/ \mathrm{ha}$, and a control were set up. Experiments were made with two replications on $26 \mathrm{~m}^{2}$ plots in both 1990 and 1991. Soil sampling and climatic conditions are shown in Table 1.

\section{Soil sampling}

Three hundred $\mathrm{ml}$ of soil was periodically collected by a soil sampler with a $100 \mathrm{ml}$ cylinder (diameter $5.04 \mathrm{~cm}, 5.0 \mathrm{~cm}$ depth) at fixed points in each plot. The collected sample was adequately mixed and the soil water content and soil volume were determined. Soil volume was calculated as follows : $5 \mathrm{~g}$ of fresh soil was added to a graduated cylinder containing $10 \mathrm{ml}$ of distilled water. The volume was increased by $5 \mathrm{~g}$ of fresh soil. The average volume of the fresh soil was $3.0 \mathrm{ml}$ (range: $2.5-3.3 \mathrm{ml}$ ). The water content in the soil samples ranged from 31 to $40 \%$. Leftover samples were frozen at $-20^{\circ} \mathrm{C}$ until used for the analysis of metolachlor residue.

\section{Extraction of metolachlor in soil}

1) Water soluble metolachlor

Thirty $\mathrm{ml}$ of distilled water was added to $10 \mathrm{~g}$ of a fresh soil sample in an Erlenmeyer flask (100 $\mathrm{ml})$. The stoppered flask was vigorously shaken by autoshaker for $30 \mathrm{~min}$.. The mixture of soil and water was separated through a Kiriyama funnel with $1 \mathrm{~g}$ of celite 545 onto glass fiber filter paper under reduced pressure. Twenty $\mathrm{ml}$ of distilled water was added to the soil sediment for washing. The metolachlor contained in the filtered and washed water was combined and extracted with $10 \mathrm{ml}$ of $n$-hexane after addition of $1 \mathrm{~g}$ of $\mathrm{NaCl}$. The extraction procedure was repeated several times. The $n$-hexane layer was dehydrated on separator filter paper (Toyo 2S). This $n$-hexane layer was then evaporated to dryness and subsequently made up to $4 \mathrm{ml}$ by acetone for gas chromatograph (GC) analysis.

2) Water insoluble metolachlor

Fifty $\mathrm{ml}$ of acetone was added to a flask containing the soil sediment which had been extracted with water as described above and the flask was allowed to stand overnight at room temperature. After vigorous shaking for $30 \mathrm{~min}$., the mixture was filtered through a Kiriyama funnel onto glass fiber filter paper. The residual soil was washed with $30 \mathrm{ml}$ of acetone and the acetone solutions were combined. The acetone-soluble extracts were concentrated under reduced pressure in a water bath kept at $40^{\circ} \mathrm{C}$, put into a separatory funnel, and added with $5 \mathrm{ml}$ of $4 \%$ $\mathrm{NaCl}$ solution. Extraction by $n$-hexane was repeated 2 times. The $n$-hexane layer was separated and dehydrated with separator filter paper (Toyo 2S). The $n$-hexane was evaporated under reduced pressure and the residue was made up to $4 \mathrm{ml}$ by acetone for GC analysis.

\section{Metolachlor determination}

Metolachlor was determined according to the 
modified analytical method for pesticide residue ${ }^{5)}$ by GC (HP 5890) equipped with a nitrogen-phosphorus flame ionization detector. The column was $2 \%$ OV-101 on Chromosorb W (100-120 mesh). The temperatures of column, detector and injection port were 200,300 and $280^{\circ} \mathrm{C}$, respectively. Carrier gas flow rates were as follows: nitrogen $24 \mathrm{ml} / \mathrm{min}$, air $100 \mathrm{ml} / \mathrm{min}$ and hydrogen $3 \mathrm{ml} / \mathrm{min}$. The detectable limit of metolachlor was $0.05 \mathrm{ppm}$ and the recovery from the soil fortified with metolachlor was over $80 \%$. Standard metolachlor used for GC analysis was contributed by CIBA-GEIGY (Japan), Ltd.

\section{Assay for inhibitory activity on plant growth}

Italian ryegrass (Lolium multiflorium Lam. cv. 'Waseaoba') was subjected to an assay of the growth inhibitory activity of metolachlor in soil. The seeds were germinated on wet filter paper in a petri dish at $25^{\circ} \mathrm{C}$ for 24 hours and the uniformly germinated seeds were placed in glass tubes $(2 \mathrm{~cm}$ diameter $\times 7 \mathrm{~cm}$ depth) which were packed with the soil from the metolachlor treated upland fields. The tubes were kept for 3 days in an incubator $\left(25^{\circ} \mathrm{C}, 4 \mathrm{klux}\right)$ and the shoot lengths of the plant were measured. Three seeds were used per tube with 4 repetitions.

\section{Results and Discussion}

\section{Residues of metolachlor in soil}

The residues of metolachlor in the soil are shown in Figs. 1 and 2. On the day of application, the herbicide's water-soluble ingredients were determined as $2 \mu \mathrm{g} / \mathrm{ml}$ fresh soil at the rate of $1.8 \mathrm{~kg} \mathrm{ai} / \mathrm{ha}$; at the rate of $3.6 \mathrm{~kg}$ ai/ha they were $5 \mu \mathrm{g} / \mathrm{ml}$ in 1990 and $7 \mu \mathrm{g} / \mathrm{ml}$ in 1991 (Fig. 1). In the same way, the water-insoluble ingredients of metolachlor were $4 \mu \mathrm{g} / \mathrm{ml}$ at $1.8 \mathrm{~kg} / \mathrm{ha}$ and 9 $\mu \mathrm{g} / \mathrm{ml}$ at $3.6 \mathrm{~kg}$ in 1990 , and $3 \mu \mathrm{g} / \mathrm{ml}$ and $7 \mu \mathrm{g} / \mathrm{ml}$ in 1991 respectively (Fig. 2). The total amount of metolachlor detected with the $1.8 \mathrm{~kg}$ and $3.6 \mathrm{~kg}$ ai/ha applications, therefore, was estimated as 6 $\mu \mathrm{g}$ and $14 \mu \mathrm{g} / \mathrm{ml}$ in 1990 , and $5 \mu \mathrm{g}$ and $14 \mu \mathrm{g} / \mathrm{ml}$ in 1991, respectively. Thus the total residues of

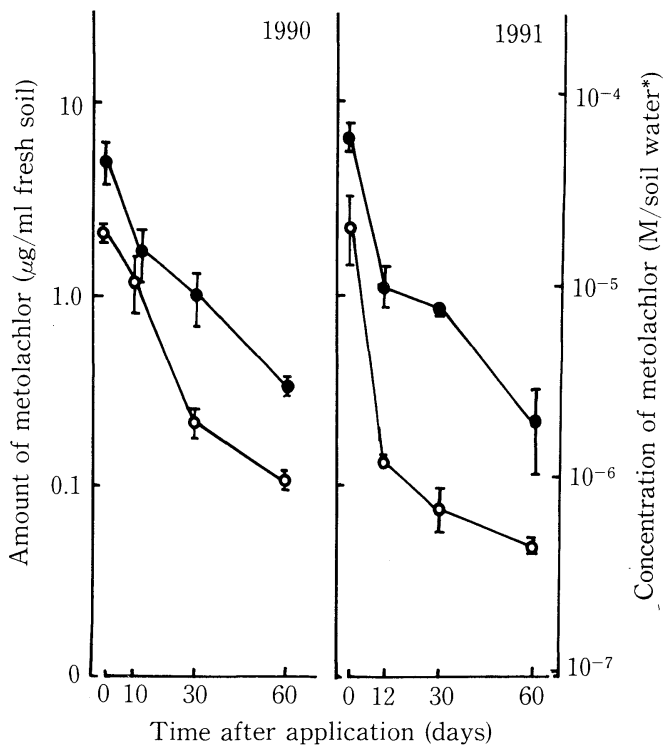

Fig. 1. Residues of water-soluble metolachlor in the field soil.

Application rate of metolachlor : $\bigcirc 1.8 \mathrm{~kg}$ ai $/ \mathrm{ha}$,

- $3.6 \mathrm{~kg} \mathrm{ai} / \mathrm{ha}$

* soil water was estimated as $40 \%$

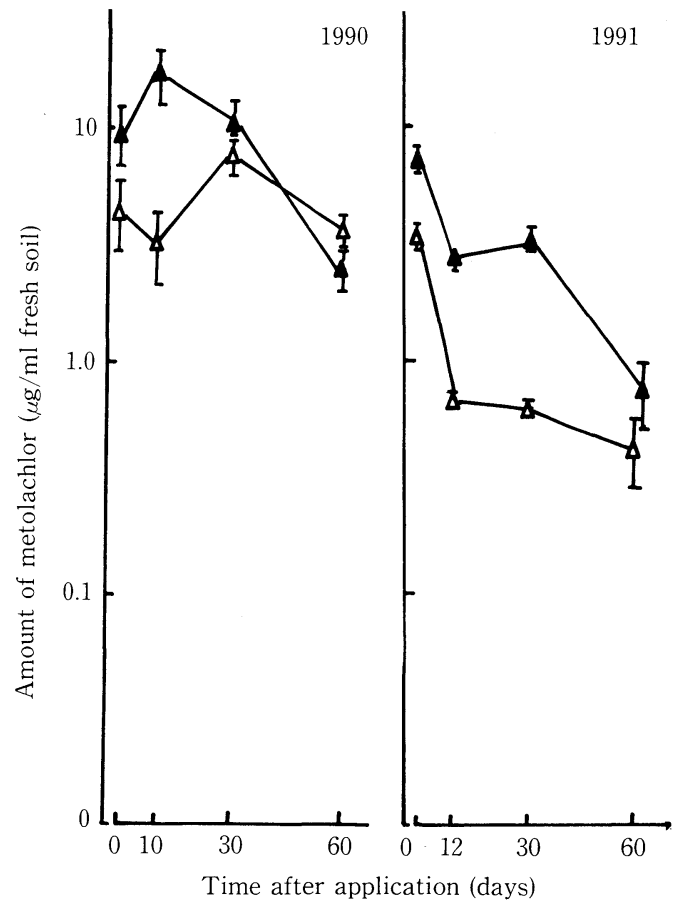

Fig. 2. Residues of water-insoluble metolachlor in the field soil.

Application rate of metolachlor : $\triangle 1.8 \mathrm{~kg}$ ai $/ \mathrm{ha}$,

А $3.6 \mathrm{~kg} \mathrm{ai} / \mathrm{ha}$ 
metolachlor on the day of application in the two years were almost idnetical.

The dissipation pattern of metolachlor in soil in 1991, however, was clearly different from that in 1990. The total residue of metolachlor in 1991 after 12 days was reduced to $0.8 \mu \mathrm{g} / \mathrm{ml}$ and 3.9 $\mu \mathrm{g} / \mathrm{ml}$ in fresh soil with $1.8 \mathrm{~kg} / \mathrm{ai}$ and $3.6 \mathrm{~kg}$ ai $/ \mathrm{ha}$ application, respectively. Bravermann et $a l^{2}$., pointed out that metolachlor probably moves through the soil profile whthin the range of 0 to 7.5 $\mathrm{cm}$ of the soil surface and that its half life fluctuates with the precipitation, being calculated to be 60 days in a year of little rainfall but 13 days in a year of enough rainfall. Walker and Zimdahl ${ }^{14)}$ also reported that the persistence of metolachlor depended on properties of the soil and suggested that it was more persistent in dry land than in irrigated land, even in the same soil.

In the present study, the half life of total metolachlor at a soil depth of 0 to $5 \mathrm{~cm}$ was calculated from the data shown in Fig. 1 and Fig. 2 to be 40 to 60 days in 1990 and 4 to 5 days in 1991. The half life of its water-soluble ingredient, however, was computed as 6 to 12 days in
1990 and 3 days in 1991 (Fig. 1). Precipitation in 1991 totaled $288 \mathrm{~mm}$, over 2 times the $136 \mathrm{~mm}$ in 1990 (Table 1). In 1991 recorded rainfall was 101. $5 \mathrm{~mm}$ during 12 days following herbicide application. These findings showed that the residue of metolachlor water-insoluble ingredient in the soil was fluctuated remarkably with precipitation, whereas the water-soluble ingredients in 1990 and 1991 dissipated similarly and showed on great fluctuation. The amount of water-soluble ingredients thus appear little affected by precipitation, in contrast to the total and water-insoluble residues of the herbicide.

\section{Inhibitory activity of metolachlor in soil on plant growth}

Italian ryegrass was cultured in fresh soils periodically collected after metolachlor application and the amount of the residual herbicide was determined. Figure 3 shows the relationship between the amount of water-soluble metolachlor and plant growth. The regression equations of 1990(a) and 1991(b) are: $\mathrm{Y}=29.2545-20.4875 \mathrm{In}$ $\mathrm{X}\left(\gamma=-0.8941^{* *}\right)$, and $\mathrm{Y}=26.7149-21.8313$ In $\mathrm{X}\left(\gamma=-0.9311^{* *}\right)$, respectively. The regression

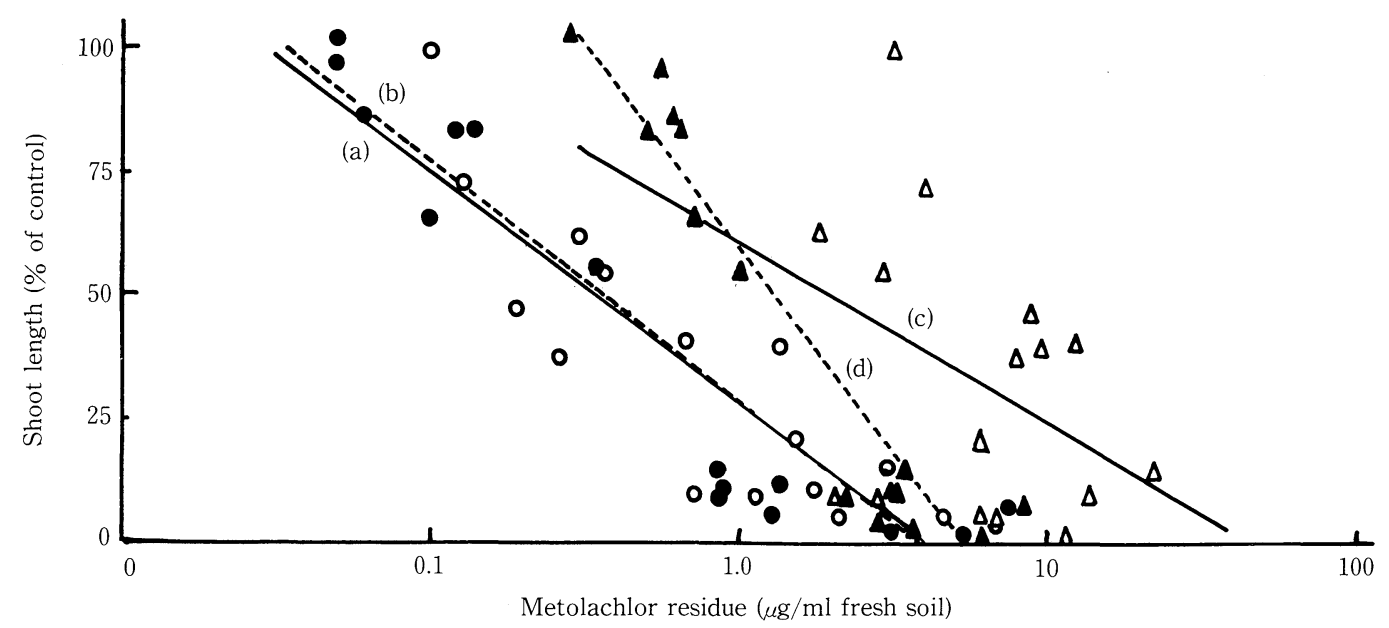

Fig. 3. Plant growth inhibition in ratio to the residual state of metolachlor in soil

(a) $\mathrm{Y}=29.2545-20.4875$ In $\mathrm{X}\left(\gamma=-0.8941^{* *}\right)$ ( $\bigcirc$ water soluble 1990)

(b) $\mathrm{Y}=26.7149-21.8313$ In $\mathrm{X}\left(\gamma=-0.9377^{* *}\right)$ (@ water soluble 1991)

(c) $\mathrm{Y}=61.2119-15.5089 \mathrm{In} \mathrm{X}(\gamma=-0.3890)(\triangle$ water insoluble 1990)

(d) $\mathrm{Y}=59.0330-36.6421$ In $\mathrm{X}\left(\gamma=-0.9550^{* *}\right)$ ( $\boldsymbol{\Delta}$ water insoluble 1991) 


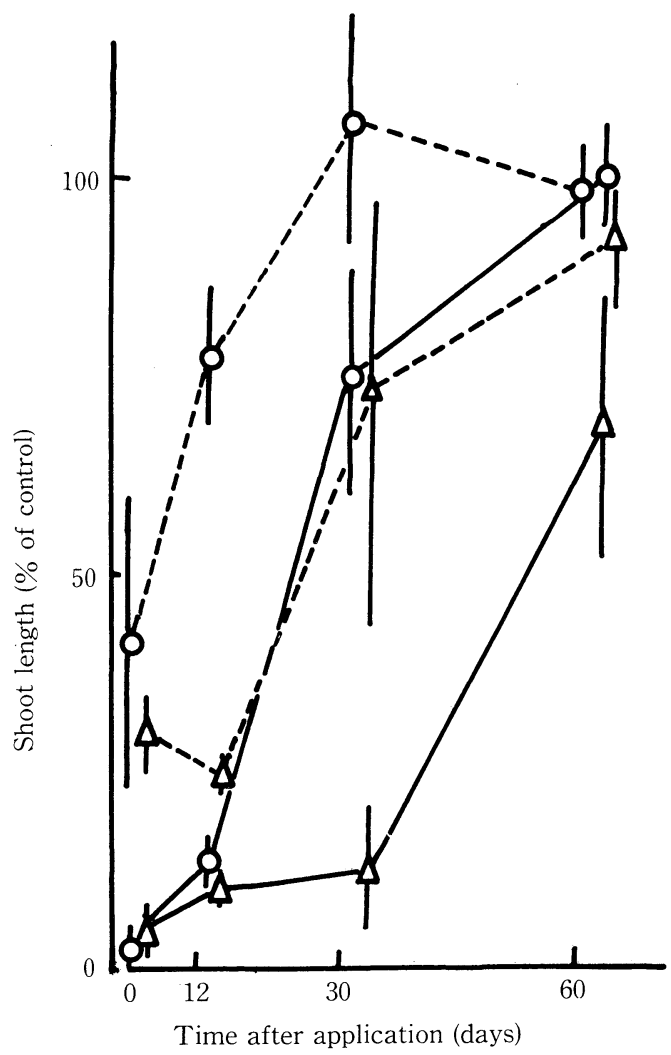

Fig. 4. Plant growth inhibition in field soils applied with metolacholr in 1991.

$1.8 \mathrm{~kg} \mathrm{ai} / \mathrm{ha}$ : $-\mathrm{O}-$ fresh soil, $\cdots \circ \cdots$ soil after extraction of water soluble metolachlor

$3.6 \mathrm{~kg} \mathrm{ai} / \mathrm{ha}:-\Delta-$ fresh soil, $\cdots \Delta \cdots$ soil after extraction of water soluble metolachlor

coefficient is almost the same in the two linear equations. Regression equations for the amount of herbicide water-insoluble ingredients and plant growth are $\mathrm{Y}=61.2119-15.5089$ In $\mathrm{X} \quad(\gamma=$ $-0.3890)$ in $1990(\mathrm{c})$ and $\mathrm{Y}=59.0330-36.6421$ In $\mathrm{X}$ $\left(\gamma=-0.9550^{* *}\right)$ in 1991 (d), respectively.

The growth of Italian ryegrass in soil without metolachlor water-soluble ingredients was also tested in 1991 and compared with growth in fresh soil (Fig. 4). Growth in the soil from which these ingredients had been extracted was little inhibited, whereas growth in the fresh soil before extraction was remarkably inhibited. In both types of soil application rate and time had a bearing on plant growth. No growth inhibition was found in soils from which water-soluble ingredients had been extracted 30 days following $1.8 \mathrm{~kg}$ ai $/$ ha application or 60 days following application of $3.6 \mathrm{~kg} \mathrm{ai} / \mathrm{ha}$ (Fig. 4), although these amount of water insoluble metolachlor remained about $1 \mu \mathrm{g} / \mathrm{ml}$ to be matched for three times dosage of $50 \%$ inhibition on plant growth by water-soluble metolachlor (Fig. 3). Evaluation of these various results appeared to indicate that the herbicidal activity of metolachlor in the soil depended on the concentration of its water soluble ingredients but was not affected by its waterinsoluble ingredients.

Coleoptile elongation of the oat, Avena sativa $\mathrm{L}$. cv. 'Victory' was significantly inhibited at a metolachlor concentration of $1 \times 10^{-6} \mathrm{M}$ when treated for 48 hours $^{4)}$. In the present study, Italian ryegrass shoot elongation was inhibited by $50 \%$ at $0.3 \mu \mathrm{g}$ of water-soluble ingredients in $1 \mathrm{ml}$ of fresh soil (Fig. 3). This inhibition seemed to correspond to oat growth, since $0.3 \mu \mathrm{g} / \mathrm{ml}$ of metolachlor was roughly estimated to be $2 \times 10^{-6}$ $\mathrm{M}$ in the soil water.

There has been no information on the herbicidal activity of metolachlor metabolites, although the metabolism of the herbicide by soil microbes has been clarified ${ }^{6,7)}$. The herbicidal activity of metolachlor metabolites in soil on plant growth was not examined in the present study; however, the results obtained here confirmed that the herbicidal activity is primarily governed by its water-soluble ingredients in soil. In flooded paddy soils, the herbicidal activity of acetanilide herbicides to rice plant was dependent on the concentration of water-soluble ingredients and was dominated by the soil properties ${ }^{11,12)}$. It thus can be postulated that the herbicidal activity of an herbicide is actually caused by the concentration of the herbicide in soil water in both upland and paddy soil. It is important to emphasize that the total amount of metolacholor residue in soil is not as much influenced by properties of 
the soil as by environmental factors, whereas the herbicide's concentration in soil water is dominated by the soil properties and environmental factors have little impact.

Acknowledgment : The authors wish to thank CIBA-GEIGY (Japan), Ltd. for contributing standard metolachlor and metolachlor formulation.

\section{References}

1) Bravermann, M.P., T.L. Lavy and R.E. Talbert 1985. Effect of metolachlor residues on rice (Oryza sativa). Weed Science 33, 819-824.

2) Bravermann, M.P., T.L. Lavy and C.J. Barnes 1986. The degradation and bioactivity of metolachlor in the soil. Weed Science 34, 479484.

3) Bouchard, D.C., T.L. Lavy and D.B. Marx 1982. Fate of metribuzin, metolachlor and fluometuron in soil. Weed Science 30, 629-632.

4) Deal, D.M. and F.D. Hess 1980. An analysis of the inhibitory characteristics of alachlor and metolachlor. Weed Science 28, 168-175.

5) Goto, S. and S. Kato 1987. Analytical method for pesticide residue (suppl) (in Japanese). Softscience, Tokyo, pp. 309-310.

6) Krause, A., W.G. Hancock, R.D. Minard, A.J. Fryer, R.C. Honeycutt, H.M. LeBaron, ShuYen Liu and Jean-Marc Bollag 1985. Microbial transformation of the herbicide metolachlor by a soil actionmycete. J. Agric. Food Chem. 33, 585-589.
7) McGahen, L.L. and J.M. Tiedji 1978. Metabolism of two new acylanilide herbicides, Antor herbicide ( $\mathrm{H}-22234)$ and Dual (metolachlor) by the soil fungus Chaetomium globosum. J. Agric. Food Chem. 26, 414-419.

8) Peter, C.J. and J.B. Weber 1985. Absorption, mobility and efficacy of alachlor and metolachlor as influenced by soil properties. Weed Science 33, 874-881.

8) Pignatello, J.J. and L.O. Haung 1991. Sorptive reversibility of atrazine and metolachlor residues in field soil samples. J. Environ. Qual. 20, 222-228

10) Rowe, J., J.J. Kells and D. Penner 1991. Efficacy and mode of action of CGA-154281, a protectant for corn (Zea mays) for metolachlor injury. Weed Science 39, 78-82.

11) Sugiyama, H., K. Komamiya and K. Kobayashi 1990. Butachlor and pretilachlor concentrations in paddy soil in relation to phytotoxicity to rice plant (in Japanese with English summary). Weed Res. Japan 35, 116-121.

12) Sugiyama, H., K. Komamiya and K. Kobayashi 1990. Mefenacet concentration in the paddy soil and its phytotoxicity to rice plant (in Japanese). Weed Res. Japan 35, 180-182.

13) Vigor, P.R., C.V. Eberlein and E.P. Fuerst 1991. Influence of available soil water content, temperature, and CGA-154281 on metolachlor injury to Corn. Weed Science 39, 227-231.

14) Walker, A. and R.L. Zimdahl 1981. Simulation of the persistence of atrazine, linuron and metolachlor in soil at different sites in the USA. Weed Research 21, 255-265.

\section{畑土壤におけるメトラクロールの残留形態と殺 草活性}

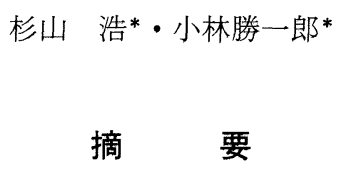

大豆播種直後に施用したメトラクロール［2-

\footnotetext{
*農林水産省農業研究センター
}

chloro-2'-ethyl-N-(2-methoxy-1-methy 1ethyl) $-6^{\prime}$-methylacetanilide] の土蚊中の残留を水 可溶態扣よび水不溶態とに分けて測定し殺草活性と の関連を調べた。土壤中の水不溶態メトラクロール 量は 1990 年と 1991 年で変動したが (Fig. 2), 水可 溶態メトラクロール量は降雨による影響が小さく （Fig. 1)，それは降水量の差に上ると考点られた (Table 1)。生土壌容積あたりのメトラクロール総 量(水不溶態执よび水可溶態メトラクロールの和)の 半減期は 1990 年では 40 日 60 日, 1991 年では 4 日 
〜 5 日であった。しかしながら水可溶態メトラク ロールの半減期は 1990 年では 6 日 12 日，1991年 では 3 日であり総量の半減期に比べ, 年次間の変動 がきわめて小さかった。メトラクロールの土壤施用 後, 定期的に採取した土壤の殺草活性を調べた。1990 年掞よび 1991 年の水可溶態メトラクロール濃度と 殺草活性との相関係数はともに高く，回帰係数も同 様の值を示した（1990：Y=29.2545-20.4875 In X $\left(\gamma=-0.8941^{* *}\right), 1991: \mathrm{Y}=26.7149-21.8313$ In $\mathrm{X}$ $\left.\left(\gamma=-0.9377^{* *}\right)\right)$ 。しかし, 水不溶態メトラクロール 濃度は, 1991 年の場合には殺草性との相関係数は高 かったが，1990 年は相関係数は低い值を示し，また 両年の回帰係数は著しく異なっていた（1990：Y= 61.2119-15.5089 In $\mathrm{X}(\gamma=0.3890), 1991: \mathrm{Y}=$ $59.0330-36.6421$ In $\left.\mathrm{X}\left(\gamma=-0.9550^{* *}\right)\right)$ (Fig. 3)。 メトラクロールを処理した生土壤と水可溶態メトラ
クロール除去土壤との殺草性を比べた結果，前者の 土壤では $1.8 \mathrm{~kg}$ ai $/ \mathrm{ha}$ の場合には 30 日後でも活性 を示したが,後者の土壤は処理当日および 12 日後の 場合でも殺草活性は生土壌に比べて著しく劣り，30 日以降では殆ど殺草性を示さなかった（Fig. 4)。以 上の結果から，土壤処理したメトラクロールの殺草 活性は土壤中に打ける本剤の総量でなく，水可溶態 メトラクロール濃度に依存していることが確かめら れた。また，土壤中に抢ける本剤の水可溶態扔よび 水不溶態量は降水量によって变動するが，土壤水分 中のメトラクロール濃度の変動は小さいので，降水 量が異なっても殺草活性は，殆ど変化しないものと 思われる

キーワード：メトラクロール，水可溶態メトラク ロール，土袞水分，土壌残留，殺草活性 